\title{
Vzpomínka na Josefa Vavrouška při příležitosti předání jeho ceny za rok 2013
}

\section{Jan Kára}

Envigogika 9 (2) - Inspirace/ Inspiration

Publikováno/Published 31. 10. 2014

DOI: $\underline{10.14712 / 18023061.457}$

\section{Abstrakt:}

Vzpomínání na Josefa Vavrouška, které přednesl Jan Kára dne 5. 6. 2014 během udílení cen Josefa Vavrouška za rok 2013.

\section{Klíčová slova:}

Josef Vavroušek

\section{Abstract:}

Reminiscences of Josef Vavroušek, delivered by Jan Kára on 5th June 2014 on the occasion of the 2013 Josef Vavroušek prize-giving ceremony.

\section{Keywords:}

Josef Vavroušek 
Když jsem byl osloven, abych zde zavzpomínal na Josefa, kterému by bylo letos 70 let, pocítil jsem velké rozpaky a zapochyboval jsem, jestli volba padla na toho pravého... těch „povolanějších" je jistě dost.

Pravda, patřil jsem nějaký čas k Josefovým blízkým spolupracovníkům, a doufám i kamarádům... Konec konců byl to Josef, který mě před více než 20 lety vytrhl z mého akademického poklidu a s nonšalantní samozřejmostí přehodil výhybky mého života.

Nevím, jestli mě toto opravňuje, abych zde mluvil, ale poctěn jsem a tedy zkusím trochu zavzpomínat:

K onomu vytržení došlo někdy na přelomu let 1990 a 1991, byla to stále ještě hodně hektická doba transformace, doba kvasu, změny a naděje - téměř dějinného optimismu, kdy se lepší svět zdál být téměř na dosah ruky. Já jsem se chtěl přiblížit tomuto proudu - a Josef byl jeho ztělesněním. Tak jsem se nechal vytrhnout.

$\checkmark$ roli poradce na dílčí úvazek jsem se na FVŽP podílel především na realizaci Josefových mezinárodních iniciativ... nebot' vedle té veškeré „domácí běžné práce", tedy vyvádění země z ekologické katastrofy a třeba dnes těžko představitelné porce environmentální legislativy počátku 90. let, měl Josef sílu a nezadržitelnou potřebu pracovat minimálně $v$ kontinentálním měřítku a dokonce spřádat plány na záchranu světa. Měl všechno systémově propojené a byl přesvědčen, že právě oblast životního prostředí (spíše než třeba ekonomika, kde mají země různé a protichůdné zájmy) je tím skutečným základem mezinárodní spolupráce.

V podmínkách, v nich jsme tehdy pracovali, čerstvě vynořeni z totality a s minimálními zkušenostmi z mezinárodních jednání, měly Josefovy nápady často punc "mission impossible". Překvapovalo nás, že trvá na jejich zhmotnění.

Práce na tom zhmotňování pak probíhala ve víceméně ustáleném „třífázovém" cyklu:

Nejprve naše pochyby, malověrnost a resistence - s tím si Josef ovšem hravě poradil třeba úsměvem či mávnutím ruky; nepřesvědčil nás úplně, ale když byl blízko, tak jsme mu věřili;

Následoval vír aktivit, které Josef urputně posouval kupředu, a kdy nebyl čas ptát se po smyslu toho, co děláme;

A když bylo hotovo, s uklidněním se opět vkrádaly pochyby...

Mluvím o Dobříšské konferenci ministrů životního prostředí Evropy v červnu 1991.

Mluvím o schůzce ministrů životního prostředí ze střední a východní Evropy v Tatrách počátkem roku 1992.

Mluvím o přípravách na světovou Konferenci OSN o životním prostředí a rozvoji v Rio de Janeiru v červnu 1992.

Mluvím o Josefových návrzích na reformu OSN. A zde se trochu zastavím:

Vypadalo to jako úplná bláhovost: zkomprimovat vizi světového řádu $v$ podstatě do jediné tabulky, do matice, kde bylo pěkně po inženýrsku nalajnováno, jak má vypadat vrcholná světová organizace, pokud má opravdu fungovat a pokud má umět reagovat na 


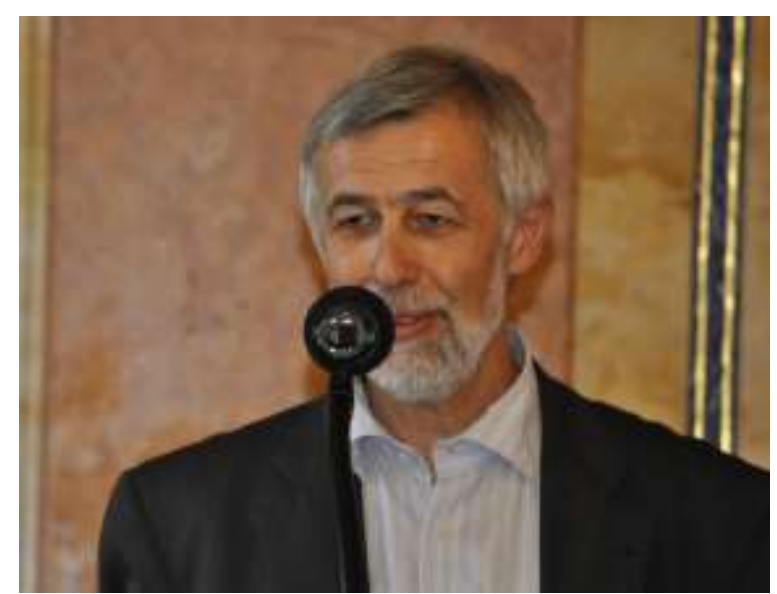

\section{Jan Kára při předávání Ceny Josefa Vavrouška 2013}

výzvy současného světa. Rozesílali jsme tuto vizi lepšího světového řádu představitelům zemí i mezinárodních organizací, pamatuju se, jak jsem byl nucen $\mathrm{s}$ touto tabulkou pobíhat po chodbách sídla OSN $v$ Ženevě a podstrkávat $\mathrm{j}$ různým pohlavárům. A tuto vizi Josef - tuším, že bez požehnání vlády - prezentoval i ve svém vystoupení na konferenci v Riu.

Ale byla to jen bláhovost? Procesně asi ano, ale myslím, že až po létech nekonečných dohadování a drobných reforem OSN do té Josefovy vize tak nějak dorůstá.

Každopádně po návratu z Ria koncem června 1992 už vývoj v Československu nabíral jiný kurz, začala de facto demontáž federace, a spousta té Josefovy (a naší) práce byla jakoby zmařena, udržitelný rozvoj se stal nežádoucím pojmem... a mohl bych pokračovat...

Teprve za této situace mi začal pomalu docházet hlubší význam Josefových iniciativ, na nichž jsem měl tu čest se (amatérsky) podílet. Docházelo mi, že Josef nejen viděl dál, ale možná i tušil, že to "okénko př́ležitosti", které se počátkem 90. let pootevřelo, je tady jen na chvíli, a že je tedy třeba jej maximálně využít.

A tím vlastně začala jakási čtvrtá "virtuální" fáze spolupráce s Josefem, fáze uvědomění, o kolik nás předběhl. Nepřervala jí ani tragická událost $v$ roháčské dolině Parichvost v březnu 1995, spíše naopak. Tahle fáze trvá dodnes. Myslím na Josefa často na jeho toleranci, odhodlání i pokoru, na jeho přímočarost horolezce "ve stěně". Myslím na něj také proto, že kolem sebe nevidím moc lidí jeho formátu.

Vlastně pořád hledám nějakého takového "Pepu Vavrouška" - někoho s vizí, s nezdolnou energií za tou vizí jít, a zároveň se schopností zachovat si neokázalou vlídnost prostého člověka...

Na závěr tedy musím konstatovat: Pepo, chybíš!

Praha, 5. 6. 2014 